\title{
Pharmacogenomics of Open-Angle Glaucoma
}

\author{
Stephen G. Schwartz ${ }^{1}$ and Tomomi Higashide ${ }^{2}$ \\ ${ }^{1}$ Bascom Palmer Eye Institute, University of Miami Miller School of Medicine, \\ ${ }^{2}$ Kanazawa University Graduate School of Medical Science, \\ ${ }^{1} U S$ \\ ${ }^{2}$ Japan
}

\section{Introduction}

Pharmacogenomics is an evolving research discipline in medicine. Within ophthalmology, the earliest candidate gene investigations have studied primary and secondary open-angle glaucoma (OAG), as well as normal tension glaucoma (NTG). At this time, pharmacogenomics data are not generally used to make clinical decisions. However, as we collect data from clinical trials, the role of pharmacogenomics in the care of patients with glaucoma and allied diseases will become clearer.

There are at least two potential future roles for applying pharmacogenomics in the treatment of OAG and allied disorders. First, more targeted therapy may lead to better treatment outcomes, with less exposure to medications in patients unlikely to respond to them. Second, pharmacogenomic research may lead to the development of novel therapies for these diseases.

\section{Pharmacogenomics of open-angle glaucoma}

Data from multiple randomized clinical trials (RCTs) have demonstrated that control of intraocular pressure (IOP) is generally effective in delaying progression of optic neuropathy and visual loss in patients with OAG, NTG, and ocular hypertension $(\mathrm{OH})$ (Vass et al., 2007). At present, two major categories of medications used to treat these disorders include $\beta$-adrenergic antagonists and prostaglandin analogs. Unfortunately, both classes of medications are associated with a number of patients who are nonresponders. For example, a secondary analysis of pooled data from phase 3 RCTs reported a nonresponse rate of $28 \%$ with the $\beta$-blocker timolol maleate and $18 \%$ with the prostaglandin analog latanoprost (Camras and Hedman, 2003).

Using current clinical examination techniques, there is no reliable way to differentiate responders from nonresponders prior to initiation of therapy. Unfortunately, this "trial and error" strategy leads to, in at least some patients, extra office visits and exposure to additional medications. The precise mechanisms of nonresponsiveness remain poorly understood, but a genetic component is suspected. It is hoped that pharmacogenomics may lead to earlier identification of nonresponders and more targeted treatment decisions (Moroi et al., 2009).

At this time, genotype-phenotype correlations have been studied, primarily using a candidate gene approach, with both $\beta$-adrenergic antagonists and prostaglandin analogs. In addition, corticosteroid treatments are frequently associated with secondary elevated IOP, and the pharmacogenomics of the steroid response have also been studied (Schwartz et al., 2008). 


\section{$2.1 \beta$-adrenergic antagonists}

There is a growing body of literature regarding the pharmacogenomics of ophthalmic $\beta$ adrenergic antagonists, although at this time there is a lack of consensus regarding clinically significant genotype-phenotype associations. The $\beta$-adrenergic antagonists include several non-selective agents ( $\beta_{1^{-}}$and $\beta_{2}$-antagonists), including timolol, and one $\beta_{1}$-selective antagonist, betaxolol. The non-selective agents are generally more effective and are therefore prescribed more frequently in the US (Allen et al., 1986). Betaxolol is associated with a high interpatient variability in response, which appears similar to the high interpatient variability in response associated with the use of systemic $\beta_{1}$-antagonists used in the treatment of systemic hypertension (Materson et al., 1993).

The $\beta_{1}$-adrenergic receptor gene contains two well-characterized single nucleotide polymorphisms (Maqbool et al., 1999). At nucleotide 145, an $A \rightarrow G$ exchange causes a serine $\rightarrow$ glycine (Ser $\rightarrow$ Gly) substitution at codon 49 (Levin et al., 2002). Gly49 is found in about $14 \%$ of both Caucasians and African Americans (Moore et al., 1999). At nucleotide 1165 , a $\mathrm{C} \rightarrow \mathrm{G}$ exchange causes an arginine $\rightarrow$ glycine (Arg $\rightarrow$ Gly) substitution at codon 389 (Mason et al., 1999). Gly389 is found in $42 \%$ of African Americans, but only $27 \%$ of Caucasians (Moore et al., 1999).

In a prospective, nonrandomized clinical trial, 48 consecutive normal volunteers were treated with betaxolol for 6 weeks. The Arg389 homozygote genotype was associated with a significantly higher baseline IOP and a significantly greater magnitude of response to betaxolol therapy. Using multivariable linear regression, the Arg389 homozygote genotype was independently associated with a higher baseline IOP and a greater magnitude of response to betaxolol therapy, even after adjusting for baseline IOP. There were no statistically significant associations found with respect to the polymorphisms at codon 49 (Schwartz et al., 2005). In a prospective study of 19 glaucoma patients and 18 normal volunteers treated with timolol, Ser49 homozygotes manifested lower heart rate, higher systolic arterial pressure, and higher diastolic arterial pressure than Gly49 carriers under the conditions evaluated (Nieminen et al., 2005). A Japanese study of 211 OAG patients, 294 patients with NTG, and 240 controls reported a significant association between NTG and the Arg389Gly polymorphism (Inagaki et al., 2006).

The $\beta_{2}$-adrenergic receptor gene contains four well-characterized single nucleotide polymorphisms (Liggett, 2000). At nucleotide -47 , a $\mathrm{T} \rightarrow \mathrm{C}$ exchange causes a cysteine $\rightarrow$ arginine (Cys $\rightarrow$ Arg) substitution at codon 19 (Parola and Kobilka, 1994). At nucleotide 46 , a $\mathrm{G} \rightarrow \mathrm{A}$ exchange causes a glycine $\rightarrow$ arginine (Gly $\rightarrow$ Arg) substitution at codon 16 (Green et al., 1993). At nucleotide 79, a $\mathrm{C} \rightarrow \mathrm{G}$ exchange causes a glutamine $\rightarrow$ glutamic acid (Gln $\rightarrow$ Glu) substitution at codon 27 (Green et al., 1994). At nucleotide 491, a $\mathrm{C} \rightarrow \mathrm{T}$ exchange causes a threonine $\rightarrow$ isoleucine ( $\mathrm{Thr} \rightarrow$ Ile) substitution at codon 164 (Green et al., 1993).

The Personalized Medicine Research Project studied 210 patients in the United States being treated with topical $\beta$-blockers. In these patients, Gln27 homozygotes were significantly more likely to experience a $20 \%$ or greater decrease in IOP following treatment, after adjusting for sex, family history of glaucoma, and use of systemic $\beta$-blockers (McCarty et al., 2008). However, other studies reported no significant associations between $\beta_{2}$-adrenergic receptor polymorphisms and clinical efficacy. In a prospective study of 89 normal volunteers treated with timolol, no association was found between the efficacy of timolol and the Arg16/Gln27, Gly16/Gln27, and Gly16/Glu27 variants (Fuchsjager-Maryl et al., 2005). In an association study with 299 OAG patients and 284 controls, no differences in $\beta_{2}-$ adrenergic receptor gene alleles and haplotypes were found (McLaren et al., 2007). 
The clinical efficacy of topical $\beta$-blockers may be affected by other genes. For example, timolol is metabolized by cytochrome P40 2D6 (CYP2D6). Polymorphisms in this gene are associated with reduced efficacy of oral timolol in patients with systemic hypertension (McGourty et al., 1985). In a series of 19 OAG patients and 18 volunteers, poor metabolizers of CYP2D6 demonstrated higher systemic concentrations of ophthalmic timolol, suggesting a potential safety concern in these patients (Nieminen et al., 2005). In a series of 133 OAG patients, systemic bradycardia following administration of topical timolol was significantly associated with the genotype at the CYP2D6 Arg296Cys polymorphism (Yang et al., 2009).

\subsection{Prostaglandin analogs}

Latanoprost is a highly selective agonist of the prostaglandin $\mathrm{F}_{2 \alpha}(\mathrm{FP})$ receptor (Stjernschantz et al., 1995). The FP receptor gene, located on chromosome 1p31.1, belongs to the family of $G$ protein coupled receptors (Betz et al., 1999).

In a prospective, nonrandomized clinical trial, 100 normal volunteers were treated with latanoprost for 1 week. Ten polymorphisms in the FP receptor gene, of which 2 were novel, were studied. The polymorphisms rs3753380 and rs3766355 showed statistically significant associations with the magnitude of response to latanoprost. The promoter assay revealed that the $\mathrm{C}$ allele of rs3766355 and $\mathrm{T}$ allele of rs3753380 were associated with lower transcriptional activity of the FP receptor gene, which was in agreement with the differences of IOP response to latanoprost based on genotypes of these polymorphisms (Sakurai et al., 2007). Using pathway analysis, the following polymorphisms were studied and found to have no statistically significant relationship with IOP reduction: T396A in prostaglandin transporter (Van Der Zwaag et al., 2002), P129T in fatty acid amide hydrolase (Sipe et al., 2002), -1607 insG in MMP-1 gene (Rutter et al., 2002), C-1306T in MMP-2 gene (Price et al., 2001), -1171 delA in MMP-3 gene (Ye et al., 1995), and C-1562T (Zhang et al., 1999) and CA repeats (-131 -90) in MMP-9 gene (St. Jean et al., 1995).

\subsection{Corticosteroid-induced glaucoma}

Some patients develop increased IOP and secondary OAG when exposed to corticosteroids. The etiology of this steroid response has never been fully explained, although a genetic determinant has been suspected for decades (Becker, 1965). Glucocorticoid receptors are present on the surface of trabecular meshwork cells, providing a possible mechanism for corticosteroid action on IOP (Weinreb et al., 1981). There are 6 well-known polymorphisms in the human glucocorticoid receptor gene (Tissing et al., 2005):

1. ER22/23EK, a GAGAGG $\rightarrow$ GAAAAG substitution, which results in a GluArg $\rightarrow$ GluLys $(\mathrm{ER} \rightarrow \mathrm{EK})$ substitution at codons 22-23 (van Rossum et al., 2002);

2. N363S, an AAT $\rightarrow$ AGT substitution, which results in an Asn $\rightarrow$ Ser $(\mathrm{N} \rightarrow \mathrm{S})$ substitution at codon 363 (Huizenga et al., 1998);

3. BclI, a $C \rightarrow$ G substitution in intron 2 (van Rossum et al., 2003);

4. N766N, an AAT $\rightarrow$ AAC substitution, which results in an Asn $\rightarrow$ Asn substitution $(\mathrm{N} \rightarrow \mathrm{N})$ at codon 766 (Koper et al, 1997);

5. a $\mathrm{G} \rightarrow \mathrm{C}$ substitution within intron 3 (Koper et al., 1997);

6. a $\mathrm{G} \rightarrow \mathrm{T}$ substitution within intron 4 . (Koper et al., 1997).

In a study of 102 patients treated with topical corticosteroids following photorefractive keratectomy, N363S heterozygotes were associated with an increased risk of elevated IOP following treatment with topical prednisolone acetate (Szabo et al., 2007). 
Intravitreal triamcinolone acetonide (IVTA) is used as an off-label treatment of several retinal diseases. Clinically significant IOP elevation has been reported in about $40 \%$ of these patients (Smithen et al., 2004). In a pilot study of 52 patients (56 eyes) treated with IVTA for various retinal diseases, no statistically significant associations were detected between any of the 6 studied polymorphisms and IOP response following treatment (Gerzenstein et al., 2008).

Other genes have been investigated for associations with the steroid response. The glucocorticoid receptor has multiple isoforms (Duma et al., 2006), and the expression of these isoforms is affected by the splicesome proteins SFRS9 (Xu et al., 2003) and SFRS5 (Yan et al., 2010), the immunophilins FKBP4 and FKBP5 (Zhang et al., 2008), and other proteins. In a series of 197 OAG patients, 107 steroid responders, and 400 controls, there were no statistically significant differences among the groups with respect to 48 polymorphisms in SFRS3, SFRS5, SFRS9, FKBP4, and the glucocorticoid receptor genes (Fingert et al., 2010).

\subsection{Pitfalls in applying pharmacogenomics to glaucoma research}

In pharmacogenomics, a positive result in one study may not be shown consistently in other studies. There are two main reasons for this discrepancy. First, different study populations may have very different baseline genetic characteristics. Second, other factors may influence drug efficacy in glaucoma patients.

\subsubsection{Differences in study populations}

Different study populations may have very different genetic characteristics. A polymorphism which is associated with nonresponsiveness to a certain medication may be insignificant in another study population because of the differences in the genetic backgrounds of subjects, or the polymorphism may not be informative due to a low minor allele frequency, or the population may be out of Hardy-Weinberg equilibrium. Therefore, interpretation of conflicting results of similar studies should be done with attention to the nature of the study populations.

\subsubsection{Factors influencing drug efficacy}

Other factors may influence drug efficacy in glaucoma patients. IOP fluctuation makes evaluation of IOP response problematic, because an IOP change involves both true pharmacological effect and spontaneous IOP fluctuations such as diurnal or day-to-day fluctuations. In addition, measurement errors in IOP are not negligible, especially when the magnitude of IOP reduction is small. Therefore, precise determination of drug efficacy is a key issue in pharmacogenomic studies of glaucoma.

\subsubsection{Baseline IOP}

Greater IOP reductions from topical medications have been reported to be associated with higher baseline IOP. For example, two studies examined the efficacy of latanoprost in patients with NTG (Rulo et al., 1996; Ang et al., 2004). Both studies showed that IOP reduction by latanoprost correlated significantly with baseline IOP.

Currently, determinants of baseline IOP level in healthy subjects or in patients with NTG are largely unknown. Given that IOP fluctuates following a circadian rhythm, which is similar to the change in the activity of the sympathetic nervous system, the relationship between polymorphisms in adrenergic receptor genes and baseline IOP level was examined in two studies. In a US-based study of racially diverse patients, baseline IOP in normal subjects was 
reported to be significantly higher in Arg389 homozygotes of the $\beta 1$-adrenergic receptor gene than in Gly389 carriers (Schwartz et al., 2005). In contrast, a study of untreated Japanese NTG patients reported that diurnal mean IOP was significantly higher for Ser49 homozygotes in the $\beta 1$-adrenergic receptor gene than for Gly49 carriers, while the polymorphism at codon 389 was unrelated to the diurnal IOP level (Gao et al., 2010). In addition, two other polymorphisms, del 301-303 in a2B-adrenergic receptor gene and del 322-325 in the a2C-adrenergic receptor gene, were associated with the difference in diurnal IOP level. The conflicting results between the two studies regarding the SNP at codon 389 in the $\beta 1$-adrenergic receptor gene may be attributed to different study populations, or to discrepancies between normal volunteers and untreated NTG patients, or to other factors.

\subsubsection{Central corneal thickness}

A thinner central cornea is a risk factor for the development of OAG, as reported by largescale clinical studies including the Barbados Incidence Study of Eye Diseases (Leske et al., 2008) and the Ocular Hypertension Treatment Study (OHTS) (Gordon et al., 2002). Furthermore, in OHTS participants, thicker corneas were associated with smaller IOP responses to $\beta$-adrenergic antagonists and prostaglandin analogues than normal or thin corneas (Brandt et al, 2004). These findings were not explained by an applanation artifact from a thin cornea.

\subsubsection{Race}

Significant associations have been reported between race and drug efficacy of $\beta$-adrenergic antagonists and prostaglandin analogs. Timolol has been reported to be less effective in black patients with glaucoma or $\mathrm{OH}$ than in nonblacks (Higginbotham et al., 2002). Travoprost was reported to be more effective, while timolol was reported to be less effective, in black patients with OAG or OH than in nonblack patients (Netland et al., 2003). However, other studies have reported no association between race and drug efficacy. For example, an analysis of OHTS participants reported no statistically significant differences in IOP response to nonselective $\beta$-adrenergic antagonists or prostaglandin analogs between selfidentified African American and Caucasian individuals (Mansberger et al., 2007).

\subsubsection{Other factors influencing evaluation of drug efficacy}

A number of other factors, including IOP fluctuations, errors in IOP measurements, and differences in medication compliance may modify the post-treatment IOP value and make the true IOP response difficult to measure. Furthermore, the true IOP response may vary over time (Takahashi et al., 2008). A one-eye trial of glaucoma medication, where the untreated eye serves as a control to subtract the IOP fluctuations, has been advocated to assess the true IOP responses (Shields, 1998). However, clinical usefulness of the one-eye trial has been questioned by several reports due to asymmetrical IOP fluctuations, especially in glaucoma patients (Chaudhary et al., 2008; Realini, 2009). Also, a one-eye trial is not suitable for drugs with contralateral effects, such as $\beta$-adrenergic antagonists. Therefore, IOP measurements at several time points before and after treatments are thought to be necessary to estimate the average of the true IOP responses for each patient.

\section{Conclusions}

There is some clinical evidence that polymorphisms in the $\beta_{1}$-adrenergic receptor gene and the FP receptor gene affect clinical response to, respectively, betaxolol and latanoprost in 
normal volunteers. The preliminary results with respect to betaxolol and latanoprost should be confirmed in patients with $\mathrm{OH}$ or OAG. The relationship between polymorphisms in the $\beta 1$-adrenergic receptor gene and clinical response to nonselective $\beta$-blockers, such as timolol, is as yet not fully determined.

At this time, there is no convincing evidence of any pharmacogenomic relationship with respect to steroid-induced glaucoma following treatment with IVTA. However, these early findings are noteworthy and merit further investigation. Any potential pharmacogenomic association with steroid response might lead to a molecular drug target for future therapy of steroid-induced glaucoma, as well as a better understanding of the steroid response.

Despite the recent advances in ophthalmic pharmacogenomics, there is still much that remains to be elucidated. For example, to our knowledge, there are currently no peerreviewed data regarding possible pharmacogenomic relationships affecting other medications used in the treatment of glaucoma, such as carbonic anhydrase inhibitors, $a_{1^{-}}$ agonists, and cholinergic agents.

Even within the systems described here, there are many additional candidate genes and pathways for future association studies. Both the $\beta$-adrenergic receptor and the FP receptor pathways utilize a second messenger system, interacting with a G-protein, a primary effector, a secondary messenger, and secondary effectors. Elements of these pathways, as well as their regulatory components, are reasonable candidates for future analysis.

\section{Acknowledgements}

This work is partially supported by NIH Center Grant P30-EY014801 and by an unrestricted grant from the University of Miami from Research to Prevent Blindness, New York, NY.

SGS has received lecture fees from Bausch + Lomb and is co-holder of a patent pending entitled "Molecular targets for modulating intraocular pressure and differentiation of steroid responders versus non-responders."

\section{References}

Allen, R.C.; Hertzmark, E.; Walker, A.M. \& Epstein, D.L. (1986).A double-masked comparison of betaxolol vs. timolol in the treatment of open-angle glaucoma. Am J Ophthalmol. 101:535-541.

Ang, A.; Reddy, M.A.; Shepstone, L.; Broadway, D.C. (2004) Long term effect of latanoprost on intraocular pressure in normal tension glaucoma. Br J Ophthalmol. 88:630-634.

Becker, B. (1965) Intraocular pressure response to topical corticosteroids. Invest. Ophthalmol. 4:198-205.

Betz, R.; Lagercrantz, J.; Kedra, D.; Dumanski, J. P. \& Nordenskjold, A. (1999) Genomic structure, $5^{\prime}$ flanking sequences, and precise localization in 1P31.1 of the human prostaglandin F receptor gene. Biochem.Biophys. Res. Commun. 254:413-416.

Brandt, J.D.; Beiser, J.A.; Gordon, M.O.; Kass, M.A.; Ocular Hypertension Treatment Study (OHTS) Group. (2004) Central corneal thickness and measured IOP response to topical ocular hypotensive medication in the Ocular Hypertension Treatment Study. Am J Ophthalmol. 138:717-722.

Camras, C.B. \&Hedman, K. (2003) Rate of response to latanoprost or timolol in patients with ocular hypertension or glaucoma. J. Glaucoma 12:466-469. 
Chaudhary, O.; Adelman, R.A.; Shields, M.B. (2008) Predicting Response to Glaucoma Therapy in One Eye Based on Response in the Fellow Eye. Arch Ophthalmol. 126:1216-1220.

Duma, D.; Jewell, C.M. \&Cidlowski, J.A. (2006). Multiple glucocorticoid receptor isoforms and mechanisms of post-translational modification.J. Steroid Biochem. Mol. Biol. 102:11-21.

Fingert, J.H.; Alward, W.L.; Wang, K.; Yorio, T. \& Clark, A.F. (2010) Assessment of SNPs associated with the human glucocorticoid receptor in primary open-angle glaucoma and steroid responders. Mol. Vis. 16:596-601.

Fuchsjager-Maryl, G.; Markovic, O.; Losert, D.; Lucas, T.; Wachek, V.; Muller, M. \&Schmetterer, L. (2005) Polymorphism of the beta-2 adrenoceptor and IOP lowering potency of topical timolol in healthy subjects.Mol. Vis. 23:811-815.

Gao, Y.; Sakurai, M.; Takeda, H.; Higashide, T.; Kawase, K.; Sugiyama, K. (2010) Association between genetic polymorphisms of adrenergic receptor and diurnal intraocular pressure in Japanese normal-tension glaucoma. Ophthalmology 117:2359-2364.e1-2.

Gerzenstein, S.M.; Pletcher, M.T.; Cervino, A.C.L.; Tsinoremas, N.F.; Young, B.; Puliafito, C.A.; Fini, M.E. \& Schwartz, S.G. (2008) Glucocorticoid receptor polymorphisms and intraocular pressure response to intravitreal triamcinolone acetonide. Ophthalmic Genetics 29:166-170.

Green, S.A.; Cole, G.; Jacinto, M.; Innis, M. \&Liggett, S. B. (1993) A polymorphism of the human beta 2-adrenergic receptor within the fourth transmembrane domain alters ligand binding and functional properties of the receptor. J. Biol. Chem. 268:2311623121.

Green, S. A.; Turki, J.; Innis, M. \& Liggett, S. B. (1994) Amino-terminal polymorphisms of the human beta 2-adrenergic receptor impart distinct agonist-promoted regulatory properties. Biochemistry 33:9414-9419.

Gordon, M.O.; Beiser, J.A.; Brandt, J.D.; Heuer, D.K.; Higginbotham, E.J.; Johnson, C.A.; Keltner, J.L.; Miller, J.P.; Parrish, R.K. 2nd; Wilson, M.R.; Kass, M.A. (2002) The Ocular Hypertension Treatment Study: baseline factors that predict the onset of primary open-angle glaucoma. Arch Ophthalmol. 120:714--720.

Higginbotham, E.J.; Schuman, J.S.; Goldberg, I.; Gross, R.L.; VanDenburgh, A.M.; Chen. K.; Whitcup, SM.; Bimatoprost Study Groups 1 and 2. (2002) One-year, randomized study comparing bimatoprost and timolol in glaucoma and ocular hypertension. Arch Ophthalmol. 120:1286-1293.

Huizenga, N. A.; Koper, J. W.; De Lange, P.; Pols, H. A.; Stolk, R. P.; Burger, H.; Grobbee, D. E.; Brinkmann, A. O.; De Jong, F. H. \& Lamberts, S. W. (1998) A polymorphism in the glucocorticoid receptor gene may be associated with an increased sensitivity to glucocorticoids in vivo. J. Clin. Endocrinol.Metab. 83:144-151.

Inagaki, Y.; Mashima, Y.; Fuse, N.; Funayama, T.; Ohtake, Y.; Yasuda, N.; Murakami, A.; Hotta, Y.; Fukuchi, T. \& Tsubota, K. Polymorphism of beta-adrenergic receptors and susceptibility to open-angle glaucoma. Mol. Vis. 12:673-680.

Koper, J. W.; Stolk, R. P.; de Lange, P.; Huizenga, N. A.; Molijn, G. J.; Pols, H. A.; Grobbee, D. E.; Karl, M.; de Jong, F. H.; Brinkman, A. O. \& Lamberts, S. W.(1997) Lack of association between five polymorphisms in the human glucocorticoid receptor gene and glucocorticoid resistance. Hum. Genet. 99:663-668. 
Leske, M.C.; Wu, S.Y.; Hennis, A.; Honkanen, R.; Nemesure, B.; BES Study Group. (2008) Risk factors for incident open-angle glaucoma: the Barbados Eye Studies. Ophthalmology 115:85-93.

Levin, M. C.; Marullo, S.; Muntaner, O.; Andersson, B. \& Magnusson, Y. (2002) The myocardium-protective Gly-49 variant of the beta 1-adrenergic receptor exhibits constitutive activity and increased desensitization and down-regulation. J. Biol. Chem. 277:30429-30435.

Liggett, S.B. (2000). Pharmacogenomics of beta-1 and beta-2 adrenergic receptors.Pharmacology 61:167-173.

Mansberger, S.L.; Hughes, B.A.; Gordon, M.O.; Spaner, S.D.; Beiser, S.D.; Beiser, J.A.; Cioffi, G.A. (2007) Comparison of initial intraocular pressure response with topical betaadrenergic antagonists and prostaglandin analogues in African American and white individuals in the Ocular Hypertension Treatment Study. Arch Ophthalmol. 125:454-459.

Maqbool, A.; Hall, A. S.; Ball, S. G. \&Balmforth, A. J. (1999). Common polymorphisms of $\beta_{1^{-}}$ adrenoceptor identification and rapid screening assay. Lancet 353:897.

Mason, D. A.; Moore, J. D.; Green, S. A. \& Liggett, S. B. (1999) A gain-of-function polymorphism in a G-protein coupling domain of the human $\beta_{1}$-adrenergic receptor. J. Biol. Chem. 274:12670-12674.

Materson, B.J.; Reda, D.J.; Cushman, W.C.; Massie, B.M.; Freis, E.D.; Kochar, M.S.; Hamburger, R.J.; Frye, C.; Lakshman, R.; Gottdiener, J.; Ramirez, E.A.; Henderson, W.G.; for The Department of Veterans Affairs Cooperative Study Group on Antihypertensive Agents. (1993). Single-drug therapy for hypertension in men: a comparison of six antihypertensive agents with placebo. N. Engl. J. Med. 328:914921.

McCarty, C.A.; Burmester, J.K.; Mukesh, B.N.; Patchett, R.B. \&Wilke, R.A. (2008). Intraocular pressure response to topical beta-blockers associated with an ADRB2 singlenucleotide polymorphism. Arch. Ophthalmol. 126:959-963.

McGourty, J.C.; Silas, J.H.; Fleming, J.J.; McBurney, A. \& Ward, J.W. (1985).Pharmacokinetics and beta-blocking effects of timolol in poor and extensive metabolizers of debrisoquin.Clin. Pharmacol. Ther. 38:409-413.

McLaren, N.; Reed, D.M.; Musch, D.C.; Downs, C.A.; Higashi, M.E.; Santiago, C.; Radenbaugh, P.A.; Allingham, R.R.; Richards, J.E.; \&Moroi, S.E. (2007). Evaluation of the $\beta_{2}$-adrenergic receptor gene as a candidate glaucoma gene in 2 ancestral populations.Arch. Ophthalmol. 125:105-111.

Moore, J.D.; Mason, D.A.; Green, S.A.; Hsu, J. \& Liggett, S. B. (1999) Racial differences in the frequencies of cardiac beta(1)-adrenergic receptor polymorphisms: analysis of c145A > G and c1165G>C. Hum Mutat. 14:271.

Moroi, S. E.; Raoof, D. A.; Reed, D. M.; Zollner, S.; Qin, Z. \& Richards, J. E. (2009) Progress toward personalized medicine for glaucoma. Expert Rev. Ophthalmol. 4:146-161.

Netland, P.A.; Robertson, S.M.; Sullivan, E.K.; Silver, L.; Bergamini, M.V.; Krueger, S.; Weiner, A.L.; Davis, A.A.; Travoprost Study Groups. (2003) Response to travoprost in black and nonblack patients with open-angle glaucoma or ocular hypertension. Adv. Ther. 20:149-163.

Nieminen, T.; Uusitalo, H.; Maenpaa, J.; Turjanmaa, V.; Rane, A.; Lundrgen, S.; Ropo, A.; Rontu, R.; Lehtimaki, T. \& Kahonen, M. (2005) Polymorphisms of genes CY2D6, 
ADRB1, and GNAS1 in pharmacokinetics and systemic effects of ophthalmic timolol.A pilot study.Eur. J. Clin. Pharmacol. 61:811-819.

Parola, A. L. \&Kobilka, B. K. (1994) The peptide product of a 5' leader cistron in the beta 2 adrenergic receptor mRNA inhibits receptor synthesis. J. Biol. Chem. 269:4497-4505.

Price, S.J.; Greaves, D.R. \& Watkins, H. (2001) Identification of novel, functional genetic variants in the human matrix metalloproteinase-2 gene: role of $\mathrm{Sp} 1$ in allele-specific transcriptional regulation. J. Biol. Chem. 276:7549-7558.

Realini, T.D. (2009). A prospective, randomized, investigator-masked evaluation of the monocular trial in ocular hypertension or open-angle glaucoma. Ophthalmology 116:1237-1242.

Rulo, A.H.; Greve, E.L.; Geijssen, H.C.; Hoyng, P.F. (1996) Reduction of intraocular pressure with treatment of latanoprost once daily in patients with normal-pressure glaucoma. Ophthalmology 103:1276-82.

Rutter, J.L.; Mitchell, T.I.; Buttice, G.; et al. (1998) A single nucleotide polymorphism in the matrix metalloproteinase-1 promoter creates an Ets binding site and augments transcription. Cancer Res. 58:5321-5325.

Sakurai, M.; Higashide, T.; Takahashi, M. \& Sugiyama, K. (2007) Association between genetic polymorphisms of the prostaglandin $\mathrm{F}_{2 \alpha}$ receptor gene and response to latanoprost. Ophthalmology 114:1039-1045.

Schwartz, S. G.; Puckett, B. J.; Allen, R. C.; Castillo, I. G. \&Leffler, C. T. (2005) $\beta_{1}$-adrenergic receptor polymorphisms and clinical efficacy of betaxolol hydrochloride in normal volunteers. Ophthalmology 112:2131-2136.

Schwartz, S. G.; Ayala-Haedo, J. A.; Kishor, K. S. \& Fini, M. E. (2008) Pharmacogenomics of open-angle glaucoma.Curr. Pharmacogenomics Personalized Med. 6:121-125.

Shields, M.B. Principles of Medical Therapy for Glaucoma. Textbook of Glaucoma. 4th ed. Baltimore: Williams \& Wilkins; 1998:378.

Sipe, J.C.; Chiang, K.; Gerber, A.L.; et al. (2002) A missense mutation in human fatty acid amide hydrolase associated with problem drug use.Proc. Natl. Acad. Sci. U S A. 99:8394-8399.

Smithen, L. M.; Ober, M. D.; Maranan, L. \&Spaide, R. F. (2004) Intravitreal triamcinolone acetonide and intraocular pressure.Am. J. Ophthalmol. 138:740-743.

St. Jean, P.L.; Zhang, X.C.; Hart, B.K.; et al. (1995) Characterization of a dinucleotide repeat in the $92 \mathrm{kDa}$ type IV collagenase gene (CLG4B), localization of CLG4B to chromosome 20 and the role of CLG4B in aortic aneurysmal disease. Ann. Hum. Genet. 59:17-24.

Stjernschantz, J.; Selen, G.; Sjoquist, B. \& Resul, B. (1995) Preclinical pharmacology of latanoprost, a phenyl-substituted PGF2 alpha analogue.Adv. Prostaglandin Thromboxane Leukot. Res. 23:513-518.

Szabo, V.; Borgulya, G.; Filkorn, T.; Majnik, J.; Banyasz, I \& Nagy, Z.Z. (2007). The variant N363S of glucocorticoid receptor in steroid-induced ocular hypertension in Hungarian patients treated with photorefractive keratectomy. Mol. Vis. 13:659-666.

Takahashi, M.; Higashide, T.; Sakurai, M.; Sugiyama, K. (2008) Discrepancy of the intraocular pressure response between fellow eyes in one-eye trials versus bilateral treatment: verification with normal subjects. J Glaucoma 17:169-174.

Tissing, W. J.; Meijerink, J. P.; den Boer, M. L.; Binkhof, B.; van Rossum, E. F.; van Wering, E. R.; Koper, J. W.; Sonneveld, P. \&Pieters, R. (2005) Genetic variations in the 
glucocorticoid receptor gene are not related to glucocorticoid resistance in childhood acute lymphoblastic leukemia. Clin. Cancer Res. 11: 6050-6056.

van der Zwaag, B.; Verzijl, H.T.; Beltran-Valero de Bernabe, D.; et al. (2002) Mutation analysis in the candidate Mobius syndrome genes PGT and GATA2 on chromosome 3 and EGR2 on chromosome 10 [letter online]. J. Med. Genet. 39:E30. Available at http://jmg.bmjjournals.com/cgi/content/full/39/6/ e30. Accessed June 30, 2002.

van Rossum, E. F.; Koper, J. W.; Huizenga, N. A.; Uitterlinden, A. G.; Janssen, J. A.; Brinkmann, A. O.; Grobbee, D. E.; de Jong, F. H.; van Duyn, C. M.; Pols, H. A. \& Lamberts, S. W. (2002) A polymorphism in the glucocorticoid receptor gene, which decreases sensitivity to glucocorticoids in vivo, is associated with low insulin and cholesterol levels. Diabetes 51:3128-3134.

van Rossum, E. F.; Koper, J. W.; van den Beld, A. W.; Uitterlinden, A. G.; Arp, P.; Ester, W.; Janssen, J. A.; Brinkmann, A. O.; de Jong, F. H.; Grobbee, D. E.; Pols, H. A. \& Lamberts, S. W. (2003) Identification of the BclI polymorphism in the glucocorticoid receptor gene: association with sensitivity to glucocorticoids in vivo and body mass index. Clin.Endocrinol. 59:585-592.

Vass, C.; Hirn, C.; Sycha, T.; Findl, O.; Bauer, P.; \& Schmetterer, L. (2007) Medical interventions for primary open angle glaucoma and ocular hypertension. Cochrane Database Syst Rev Oct 17;(4):CD003167.

Weinreb, R.N.; Kashiwagi, K.; Kashiwagi, F.; et al. (1997) Prostaglandins increase matrix metalloproteinase release from human ciliary smooth muscle cells. Invest. Ophthalmol. Vis. Sci. 38:2772-2780.

$\mathrm{Xu}$, Q.; Leung, D.Y.; Kisich, K.O. (2003) Serine-arginine-rich protein p30 directs alternative splicing of glucocorticoid receptor pre-mRNA to glucocorticoid receptor beta in neutrophils. J. Biol. Chem. 278:27112-27118.

Yan, X.B.; Tang, C.H.; Huang, Y.; Fang, H.; Yu, Z.Q.; Wu, L.M.\& Liu, R.Y. (2010) Alternative splicing in exon 9 of glucocorticoid receptor pre-mRNA is regulated by SRp40. Mol. Biol. Rep. 37:1427-1433.

Yang, Y.; Wu, K.; Yuan, H.; Yu, M. (2009) Cytochrome oxidase 2D6 gene polymorphism in primary open-angle glaucoma with various effects to ophthalmic timolol. J. Ocul. Pharmacol. Ther. 25:163-171.

Ye, S.; Watts, G.F.; Mandalia, S.; et al. (1995) Preliminary report: genetic variation in the human stromelysin promoter is associated with progression of coronary atherosclerosis. Br. Heart J. 73:209-215.

Zhang, B.; Ye, S.; Herrmann, S.M.; et al. (1999) Functional polymorphism in the regulatory region of gelatinase $\mathrm{B}$ gene in relation to severity of coronary atherosclerosis. Circulation 99:1788-1794.

Zhang, X.; Clark, A.F. \&Yorio, T. (2008) FK506-binding protein 51 regulates nuclear transport of the glucocorticoid receptor beta and glucocorticoid responsiveness. Invest. Ophthalmol. Vis. Sci. 49:1037-1047. 


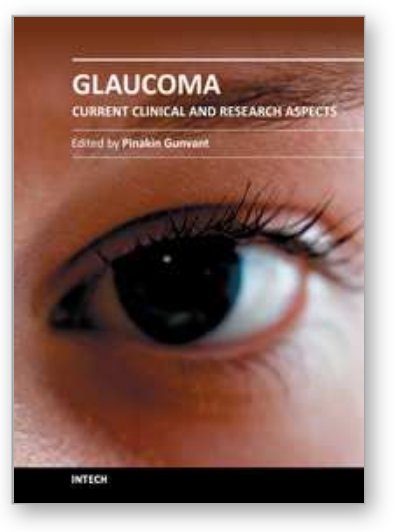

\author{
Glaucoma - Current Clinical and Research Aspects \\ Edited by Dr. Pinakin Gunvant
}

ISBN 978-953-307-263-0

Hard cover, 376 pages

Publisher InTech

Published online 09, November, 2011

Published in print edition November, 2011

This book summarizes current literature about research and clinical science in glaucoma and it is a synopsis and translation of the research conducted by individuals who are known in each of their respective areas. The book is divided into two broad sections: basic science and clinical science. The basic science section examines bench- and animal-modeling research in an attempt to understand the pathogenesis of glaucoma. The clinical science section addresses various diagnostic issues and the medical, laser and surgical techniques used in glaucoma management.

\title{
How to reference
}

In order to correctly reference this scholarly work, feel free to copy and paste the following:

Stephen G. Schwartz and Tomomi Higashide (2011). Pharmacogenomics of Open-Angle Glaucoma, Glaucoma - Current Clinical and Research Aspects, Dr. Pinakin Gunvant (Ed.), ISBN: 978-953-307-263-0, InTech, Available from: http://www.intechopen.com/books/glaucoma-current-clinical-and-researchaspects/pharmacogenomics-of-open-angle-glaucoma

\section{INTECH}

open science | open minds

\section{InTech Europe}

University Campus STeP Ri

Slavka Krautzeka 83/A

51000 Rijeka, Croatia

Phone: +385 (51) 770447

Fax: +385 (51) 686166

www.intechopen.com

\section{InTech China}

Unit 405, Office Block, Hotel Equatorial Shanghai

No.65, Yan An Road (West), Shanghai, 200040, China

中国上海市延安西路 65 号上海国际贵都大饭店办公楼 405 单元

Phone: +86-21-62489820

Fax: +86-21-62489821 
(C) 2011 The Author(s). Licensee IntechOpen. This is an open access article distributed under the terms of the Creative Commons Attribution 3.0 License, which permits unrestricted use, distribution, and reproduction in any medium, provided the original work is properly cited. 